\title{
Monitoring of Brucellosis in Agricultural Animals in Ukraine During 2013-2015
}

\author{
Oleg Nevolko* \\ State Scientific Research Institute of Laboratory Diagnostics and Veterinary and Sanitary Expertise, Kyiv, Ukraine
}

\section{Objective}

Analysis of brucellosis monitoring in agricultural animals in Ukraine to control epizootic situation and prevent possible brucellosis in humans.

\section{Introduction}

Brucellosis is one of the most widespread zoonosis in the world. Only 17 countries informed WHO that their territory is free from brucellosis. About 500 thousand cases of brucellosis in humans are registered in the world each year. The problem of brucellosis has remained actual to agriculture and health care for many years. Almost all agricultural animals are highly susceptible to brucellosis. Socio-economic significance of brucellosis problem is determined by peculiarities of the course of the disease and the main contingent that can be infected, namely the working population that is connected with both professional factors and social reasons. Brucellosis is a chronic infectious disease. The disease in animals has the following signs: abortions and retention of secundines, orchitis, unviable litter and sterility. Brucellosis is included to the list of quarantine diseases due to its social threat.

\section{Methods}

Studies of blood sera of cattle, small ruminants, horses and pigs from different Ukrainian regions that were selected during the annual spring clinical examination in 2013-2015. The following serological methods were used for the studies: complement-fixation test (CFT), agglutination reaction (AR), Rose Bengal test (RBT), prolonged complement fixation test (PCFT).

\section{Results}

Currently, Ukraine is free from brucellosis of animals. The last brucellosis case in pigs was registered in 2008 in Odesa Oblast. The last case of brucellosis in cattle in Ukraine was registered in 1992.

According to the Ministry of Health, a case of brucellosis in humans is registered in Ukraine almost every year.

Annual serological brucellosis studies of servicing bulls, cows, heifers older than one year, horses, stud rams, ewes, boars and sows are held once a year in Ukraine.

During 2013-2015, the monitoring serological brucellosis studies of blood sera from cattle, small ruminants, horses and pigs from different farms in 25 oblasts of Ukraine were conducted at State Laboratories of Veterinary Medicine and State Scientific and Research Institute of Laboratory Diagnostics and Veterinary and Sanitary Expertise.

\section{Table 1. Serological research results}

In 2013, seropositive results were obtained in AR Crimea - six cases in cattle, Dnipropetrovsk oblast - 12, Kyiv oblast - 31, Sumy oblast -118 , and Luhansk oblast - 25 using AR and RBT techniques. In small ruminants, seropositive results were determined in Luhansk oblast -26 animals (AR). Testing pigs by RBT showed the following positive results: 82 animals in Dnipropetrovsk oblast, 16 in Luhansk, and 1 in Sumy oblast. Twenty seven horses were detected positive by RBT in Luhansk oblast.

Fig. 1. Brucellosis monitoring results, 2013

In 2014, seropositive results in cattle were received in Kyiv (20), Dnipropetrovsk (28), Sumy (66), Chernihiv (37) and Zhytomyr (2) oblasts using AR, RBT, and CFT. AR tests were positive for one small ruminant in Dnipropetrovsk and for three in Sumy oblasts. Five seropositive pigs were found in Sumy oblast using RBT.

Fig. 2. Brucellosis monitoring results, 2014

In 2015, seropositive results (AR, RBT, and CFT) in cattle were obtained in Sumy (8 animals), Dnipropetrovsk (34), and Chernihiv (10) oblasts. For small ruminants, one seropositive animal was found in Dnipropetrovsk and three in Sumy oblasts using AR. Employing RBT, one pig was diagnosed in Dnipropetrovsk oblast. Two horses were found positive using RBT and AR in Sumy oblast.

Fig. 3. Brucellosis monitoring results, 2015

The seropositive animals were destroyed. Bacteriological studies were not conducted.

\section{Conclusions}

1. During the studies of blood sera of agricultural animals from different Ukrainian regions, positive results were obtained in 7 oblasts of Ukraine indicating a possible circulation of the causative agent of brucellosis.

2. Studies need the in-depth analysis that must include bacteriological testing of seropositive animals.

Table 1

\begin{tabular}{|c|c|c|c|}
\hline Year & 2013 & 2014 & 2015 \\
\hline Samples from cattle & 3304039 & 3076678 & 2942930 \\
\hline Positive samples & 192 & 250 & 52 \\
\hline Samples from small ruminants & 518028 & 492550 & 461766 \\
\hline Positive samples & 26 & 3 & 4 \\
\hline Samples from pigs & 253385 & 212966 & 204920 \\
\hline Positive samples & 99 & 5 & 1 \\
\hline Samples from horses & 8636 & 6342 & 5633 \\
\hline Positive samples & 27 & - & 2 \\
\hline
\end{tabular}

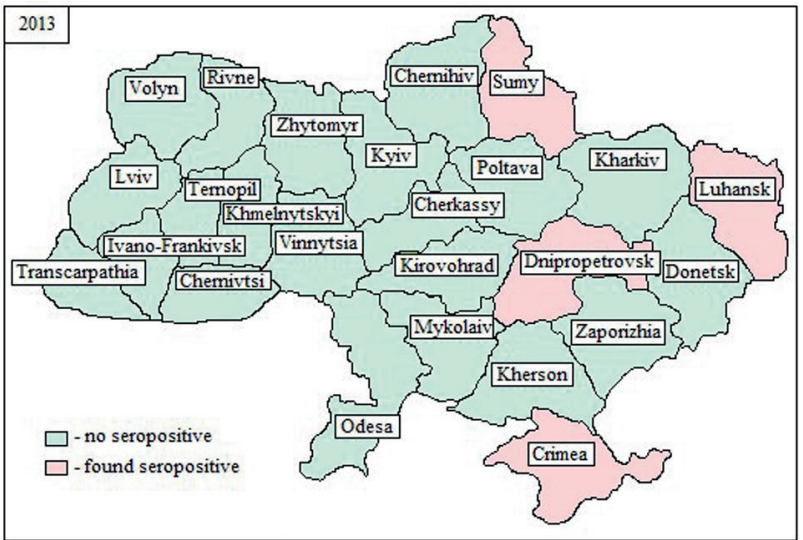



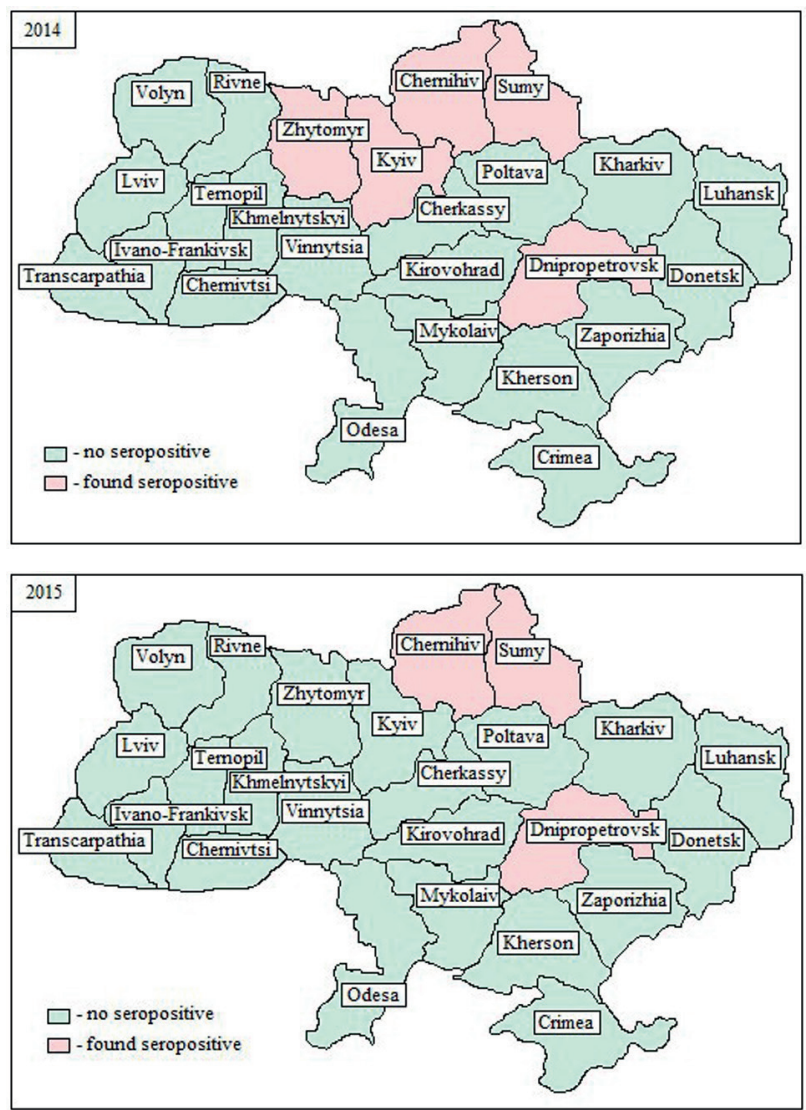

\section{Keywords}

Brucellosis; Monitoring; Serology; Ukraine

\section{*Oleg Nevolko}

E-mail: olegnevolko2010@ukr.net 